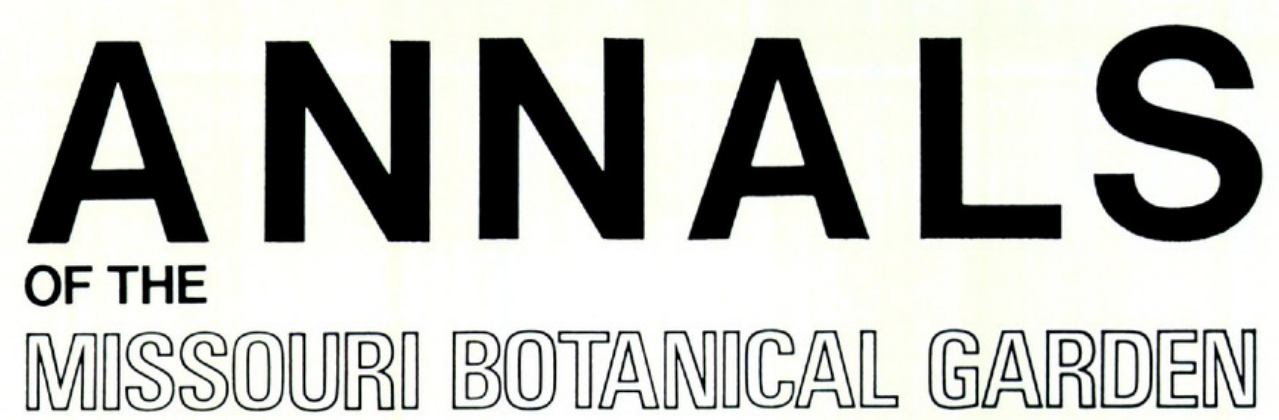

\title{
DISPERSAL VERSUS GENE FLOW IN PLANTS ${ }^{1}$
}

\author{
Donald A. LeVIN ${ }^{2}$
}

AbSTRACT

The notions that gene flow in plants is restricted and that neighborhood size and area are small are based upon data on pollination, and pollen and seed dispersal. However, neighborhood size and area estimates from these data incorporate several assumptions: (1) Pollinator flight distance is representative of pollen dispersal distance; (2) All pollen picked up by pollinators from one plant is deposited on the next one visited; (3) Pollinator flights between plants are random in direction; (4) Pollen-pistil compatibility is independent of the proximity of egg and pollen parents; (5) Seed viability is independent of the proximity of egg and pollen parents; (6) Seed production is independent of the proximity of seeds to the source; (7) The fitness of plants is independent of the distance between egg and pollen parent. These assumptions have been found to be unwarranted in many instances leading to the following conclusions: (1) Pollen carry-over may be considerable; (2) Pollinator flight sequences have a directional component; (3) Pollen-pistil compatibility may be lower among near-neighbors than among moderately spaced plants; (4) Seed abortion may be higher following self and near-neighbor crosses than following wide crosses; (5) Seed-set may be lower following crosses of neighboring plants than widely spaced plants; (6) Seed and seedling mortality may increase as the seed source is approached; (7) Fitness of offspring from distant crosses may be superior to that from self or nearneighbor crosses; (8) Gene flow over some distance may be higher in natural populations than in crops. There is abundant reason to believe that dispersal data underestimate gene flow. As a consequence, we may conclude that neighborhood sizes and areas are larger, there is less potential for random differentiation, there is less isolation by distance, there is less potential for geographical differentiation, and that stronger selection is needed to foster and maintain local differences than judged from dispersal data alone. Nevertheless, even if gene flow distances were twice as large as we now think, the spatial scale of gene dispersal: (1) is still small enough to allow substantial differentiation over short distances with moderate selective differentials, and (2) is too small to be a major cohesive force within a species.

In 1969, Ehrlich \& Raven challenged the prevailing view that plant species were Mendelian populations integrated by gene flow. They argued that gene flow probably is much too restricted to homogenize anything but local gene pools. They pointed to selection as the primary cohesive and disruptive force in evolution. Selection would determine the influence of gene flow, often counterbalancing it in the course and maintenance of microgeographic differentiation.

${ }^{1}$ This study was supported in part by National Science Foundation Grant DEB 78-23654. I am indebted to John Endler and Verne Grant for suggesting several ways to improve the paper.

${ }^{2}$ Department of Botany, University of Texas, Austin, Texas 78712.

Ann. Missouri Bot. Gard. 68: 233-253. 1981. 
The general model of restricted gene flow has received substantial support from the crop and native plant literature on pollinator foraging behavior, and pollen and seed dispersal (Levin \& Kerster, 1974; Levin, 1979). For the most part, pollinators fly from a plant to one of its near neighbors, suggesting that crosspollinations are principally between neighboring plants. Animal- and wind-borne pollen dispersal tends to assume a leptokurtic distribution, with most pollen being deposited within a few meters of the source. In most species, pollen is rarely transported beyond $1000 \mathrm{~m}$. Seeds also tend to be distributed narrowly about the source and are rarely carried beyond $200 \mathrm{~m}$.

Data from pollinator foraging behavior, and pollen and seed dispersal may be incorporated into population genetic models to obtain a first approximation of the breeding structure of populations (Levin \& Kerster, 1974). In the process, a number of simplifying assumptions typically are made. These are as follows: (1) pollen picked up by a pollinator is deposited on the next plant visited; (2) pollinator flights between plants is random in direction; (3) pollen-pistil compatibility, seed viability and seed-set are independent of pollen to egg parent distances; (4) seed and seedling survivorship are independent of the proximity to the seed source; (5) populations have no seed pool; (6) interpopulation gene flow is independent of population size and patterns of plant distribution.

The major purpose of this paper is to test these assumptions. I will show that dispersal data underestimate the expanse of gene flow, but that the breeding structure of populations is still sufficiently restricted in space to permit selective differentiation over short distances.

\section{Pollinator Foraging Behavior and Pollen Flow}

Pollen flow distances would be distributed as pollinator flight distances were all pollen collected from one plant deposited on the next visited by a pollinator. Given the inefficiency of the pollen transport mechanism, it seems likely that there would be carry-over to a second, third or fourth plant. Thomson \& Plowright (1980) were able to assess the functional form and extent of pollen carryover in the bumblebee-pollinated Erythronium americanum by introducing a single red-pollen flower into a bees foraging sequence, and examining successively visited yellow-pollen flowers. Pollen usually was deposited on 7 or more flowers. In one sequence, pollen was deposited on several flowers through the 20th and then on numbers $23,25,29$, and 54 . In most sequences maximum pollen loads were deposited on the second flower or subsequent ones; and the deposition schedule was platykurtic. Thomson \& Plowright also analyzed carry-over in bumblebee-pollinated Clintonia borealis and Diervilla lonicera using emasculated flowers. Pollen usually was carried beyond the fifth flower (often to the eighth). In many runs the initial fall-off of pollen loads roughly approaches a negative exponential function.

Before considering the extent to which pollen carry-over increases the distance pollen is transported, it is necessary to consider whether pollinators forage at random with regard to direction in successive flights. Zimmerman (1979) argued that in a population where the probability of revisiting any specific flower was small, pollinators should forage at random with regard to the direction of successive moves; i.e., angles of departures should have a uniform distribution. He 
TABLE 1. Pollen dispersal as influenced by pollen carry-over and flight directionality.

\begin{tabular}{|c|c|c|c|}
\hline \multirow[b]{2}{*}{ Carry-over Schedule } & \multicolumn{3}{|c|}{ Direction Constant $^{\mathrm{a}}$} \\
\hline & $\mathrm{D}=0$ & $\mathrm{D}=0.71$ & $\mathrm{D}=1$ \\
\hline A. $\mathrm{I}^{\mathrm{b}}=50 \%, \mathrm{II}=20 \%, \mathrm{III}=15 \%, \mathrm{IV}=10 \%, \mathrm{~V}=5 \%$ & 1.35 & 1.57 & 2.00 \\
\hline $\begin{array}{l}\text { B. I }=40 \%, \text { II }=10 \%, \text { III }=10 \%, \text { IV }=10 \%, \mathrm{~V}=10 \%, \mathrm{VI}= \\
10 \%, \mathrm{VII}=10 \%\end{array}$ & 1.74 & 2.12 & 3.10 \\
\hline $\begin{array}{l}\text { C. I }=20 \%, \text { II }=10 \%, \text { III }=20 \%, \text { IV }=10 \%, \text { V }=20 \%, \text { VI }= \\
10 \%, \text { VII }=10 \%\end{array}$ & 1.84 & 2.45 & 3.70 \\
\hline $\begin{aligned} \text { D. } I=20 \%, \text { III }=20 \%, \mathrm{~V}=20 \%, \text { VII }=10 \%, \text { IX }=10 \%, \\
X I=10 \%, \text { XIII }=10 \%\end{aligned}$ & 2.25 & 3.30 & 5.80 \\
\hline E. $I=50 \%, V=20 \%, X=10 \%, X I I=10 \%, X X=10 \%$ & 1.59 & 3.67 & 6.00 \\
\hline
\end{tabular}

a Direction Constant $\times$ Mean Flight Distance $=$ Mean Pollen Dispersal Distance; $D=0$ refers to random flights; $\mathrm{D}=1$ unidirectional flights; $\mathrm{D}=0.71$ observed directionality.

${ }^{b}$ Roman numerals refer to plant number in a sequence.

observed that the bumblebee Bombus flavifrons forages randomly with respect to direction on Polemonium foliosissimum. Likewise, Gill \& Wolf (1977) reported that the departure direction for sunbirds (Nectarinia sp.) feeding on Leonotis nepetifolia was usually independent of the arrival direction. On the other hand, strong directional components to pollinator foraging have been reported in the case of Bombus sp. working Aconitum columbianum and Delphinium nelsonii (Pyke, 1978), Bombus on Armeria maritima and Limonium vulgare (Woodell, 1978), sweatbees (Halictidae) on Convolvulus arvensis (Waddington, 1979), various bees and butterflies on Lythrum salicaria (Levin et al., 1971), and Apis mellifera on artificial flowers (Waddington, 1980). A correlation in the direction of successive flights increases the distance pollen is carried, if there is pollen carry-over.

The specific effects of pollen carry-over and directionality on pollen dispersal are best described with a series of simple models. Consider first a case of pollen carry-over with no directional component to foraging. The mean pollen dispersal distance with carry-over equals the flight mean $\times[\Sigma$ proportion pollen deposited on the $\mathrm{i}^{\text {th }}$ plant $\times \sqrt{\mathrm{i}}$ ] (Levin et al., 1971); $\mathrm{i}^{\text {th }}$ plant in a random foraging bout is (on the average) $\sqrt{i}$ plants from the pollen source. The extent to which carryover increases pollen dispersal beyond pollinator flight moves is shown in Table 1. The percentage increase is dependent on the carry-over schedule, the more liberal the schedule the larger the effect. Note that regardless of the schedule, carry-over increases the mean pollen dispersal distance several percent.

The effect of directionality of pollen dispersal distance is most easily demonstrated if we assume that pollinators fly in a straight line. With random pollination, the $\mathrm{i}^{\text {th }}$ plant is $\left(\mathrm{i}^{0.5}\right) \times($ mean flight distance) from the location of the pollen donor. With all flights in the same direction, the exponent of the $\mathrm{i}^{\text {th }}$ plant is 1 , so that the $\mathrm{i}^{\text {th }}$ plant is $\left(\mathrm{i}^{1}\right) \times$ (mean flight distance) from the pollen source. The mean pollen dispersal distance with unidirectionality is the (mean pollinator flight distance $) \times\left(\Sigma\right.$ proportion of pollen deposited on the $\mathrm{i}^{\text {th }}$ plant $\left.\times \mathrm{i}^{1}\right)$. Let us assume that $50 \%$ of the pollen from a plant is deposited on the first plant, $20 \%$ on the second, $15 \%$ on the third, $10 \%$ on the fourth, and $5 \%$ on the fifth plant visited. The mean dispersal distance with this carry-over schedule is twice that of the 
mean flight distance. With random foraging, the dispersal mean is $35 \%$ greater than the flight mean. The effect of directionality when combined with other carryover schedules is summarized in Table 1.

Having considered the consequences of carry-over within the context of no directionality and complete directionality, let us turn to a more realistic scenario, one involving moderate directionality as observed in natural populations. With a positive correlation in arrival and departure directions, the mean distance of the $\mathrm{i}^{\text {th }}$ plant from the pollen source is between $\mathrm{i}^{0.5}$ and $1^{1} \times$ (mean flight distance), the exponent increasing as the correlation increases (Levin et al., 1971). The exponents based on field observations vary from 0.69 and 0.72 for honeybees and butterflies, respectively, on Lythrum salicaria (Levin et al., 1971) to 0.85 for bumblebees on Aconitum and Delphinium (Pyke, 1978). Using 0.71 as a representative exponent, I calculated the effect of moderate directionality coupled with various carry-over schedules on pollen dispersal. The results are presented in Table 1. The mean pollen dispersal distance is increased by a factor of 1.5 to more than 3 . Thus pollen may move substantially farther than we would surmise from pollinator foraging data. Carry-over and directionality open the breeding structure of populations.

Thus far we have seen evidence for and consequences of pollen carry-over and flight directionality. It is important to recognize that neither carry-over schedules nor the magnitude of directionality are fixed attributes of a plant-pollinator relationship. Rather, both are dependent on the amount of floral reward; and this has some interesting implications for pollen dispersal. As noted earlier, Thomson \& Plowright (1980) documented carry-over schedules by analyzing pollen deposition levels in relation to the number of pollinator moves from the pollen source. In addition to employing unmanipulated flowers, they provided bees alternately with nectar-enriched and nectar-drained flowers of Diervilla lonicera. Taking run and sequence position into account, enriched flowers received significantly more pollen than drained ones. Pollen deposition per flower, or more precisely the fraction of the load deposited, is a simple function of the time spent on the two flower types; significantly more time is spent on enriched flowers. Heinrich (1979b) also studied the relationship between time and floral reward. He analyzed foraging behavior of Bombus terricola workers in a field of Trifolium repens in which sectors had been screened for two days to exclude foragers. On the average, bees foraging in the rich clover patches visited 2.95 heads per minute compared to 18.9 heads per minute in the depleted clover patches. Bees in the rich clover probed into 11.6 florets/head, vs. 2.3 florets/head in the depleted clover. It is likely that much more pollen was deposited per head in the rich patches than in the depleted ones. Correlatively, there was probably much less carry-over in the rich patches.

Bees also modify their directionality in response to resource quality. Pyke (1978) showed that the mean angular deviations of Bombus arrivals and departures on inflorescences of Aconitum columbianum and Delphinium nelsonii increased as the number of flowers visited per inflorescence increases. Thus as nectar reward per inflorescence increases, there is less correlation between successive flights, and pollinators will tend to stay in an area. Heinrich (1979b) monitored the angular deviation of Bombus on successively visited clover heads 
in rich and depleted patches. In the rich patches bees had high angular deviations, whereas bees tended to pass through patches where resources per flower were low. This aspect of foraging behavior is consistent with that described for predators feeding on prey (cf. Pyke et al., 1977).

It is possible that directionality may vary as a function of plant density. Pollinators might move more directly and rapidly through a population if the energy gain : expenditure ratio were relatively low because of large interplant distances. If pollinators are found to move with greater directionality as density declines, this behavior would compound the effect of low density on flight distance and thus on pollen flow. The lower the density the greater is the mean flight distance (Levin \& Kerster, 1974). If a sparse population also had small plants, then the level of directionality and flight distance would be high, and jointly result in unusually (for the species) broad pollen dispersal.

Bee flight distance as well as directionality varies with resource qualty. In the case of Bombus flavifrons workers on Aconitum columbianum, the mean distance moved by bees from one inflorescence to another decreases toward an asymptote as the number of flowers on an inflorescence increases (Pyke, 1978). Pyke regards the numbers of flowers visited per inflorescence as an indicator of resource quality, so that as quality declines flight distance increases. Bombus terricola foraging on Trifolium repens displays the same general behavior. The distances of interhead moves in depleted patches was approximately twice that in rich patch, i.e., patches that were screened for two days (Heinrich, 1979a). On the average, bees foraging in the depleted patches rejected (without landing or probing) $27 \%$ of the flower heads they approached. When they entered rich patches, they rarely $(0.4 \%)$ rejected heads they approached.

The foraging movements (viz. directionality and distance) described by Pyke (1978) and Heinrich (1979b) follow patterns predicted by mathematical models based on optimal foraging. Accordingly, we would expect other types of bees and indeed other categories of pollinators to forage in a similar manner. Given that pollinators respond to resource quality as the Bombus species, pollen flow will be considerably greater in depauperate populations than in rich ones. Since this condition will most likely vary through time, the same population may be both depauperate and rich, and correlatively have different pollen dispersal profiles over time. When nectar levels are very low due to temperature or moisture stress (Percival, 1965), pollen flow may be relatively broad for a considerable period.

If pollinators respond to single flowers or inflorescences in predictable ways, they probably would also respond to the entire plant in the same ways, were the sum of the open flowers at some time the measure of quality. If site quality is poor, plants would produce few flowers per unit time, and have relatively few open flowers at any one time. A pollinator may "treat" this population as nutritionally depauperate because the energy gain per plant is small, and as a consequence move farther and in a more directional manner than if the plants had numerous flowers. Accordingly, pollen dispersal would be more widespread than usual in a marginal site. On the other hand site quality may be unusually good, and plants may be unusually florificent. Then pollen flow might be more restricted than usual.

The discussion thus far has considered only pollination of single plant species. 
However, pollinators are not completely flower constant in natural communities. There is usually some switching of species by lepidopterans, hummingbirds, bumblebees, and to a lesser extent by honeybees (Baker \& Hurd, 1968; Free, 1970; Proctor \& Yeo, 1973). Individual bumblebees typically major on plant species and minor on one or a few others (Heinrich, 1976, 1979a). A minor species may differ manifestly from the major in its floral architecture and correlatively have its pollen transported in a position different from that of the major. Accordingly, pollen from a minor plant is apt to be transported to other minor plants even though several majors may intervene. Even if floral structures were similar, some pollen of the minor probably would be transported to another minor. By virtue of the fact that minor plants only intermittently are visited, cross-pollination among them often will be between widely spaced conspecifics, the distances being much larger than if the species were a major. Carry-over of minor pollen would augment the effect. Thus by virtue of being treated as a minor, the breeding structure of a species may be substantially enlarged. A given plant species may not be treated as a minor by all bees in a population. In that case, the pollen dispersal profile will be a composite of a typical leptokurtic distribution and a collection of relatively long distance events residing in the tail of that distribution.

\section{Potential Versus Actual Gene Flow}

Whereas the foraging behavior of pollinators suggests where pollen may be transported, the actual dispersal of pollen and hence pollen-mediated gene flow may be determined by the dispersion of genetic markers relative to a central point in a population. If we introduce a homozygous dominant genetic marker into a population, allow pollen to be dispersed, collect seed at various distances from the source, and determine the percentage hybrid plants as a function of distance, we would have a reasonably accurate measure of gene flow in that population. If we observed pollinator flight distances from the marker, we would then be able to compare flight and gene flow distances. Were all pollen deposited on the first plant visited, then pollinator flight and gene flow distributions would be concordant. Pollen carry-over would result in the divergence of the two distributions, the greater the carry-over the more discordant the distributions.

In 1973 I began an investigation of gene flow in natural populations of Phlox drummondii, a spring-flowering annual of central Texas. I introduced a core of ca. 100 plants of a cultivar (Twinkle) into an extensive population near Gonzales, Texas. The cultivar was homozygous for a dominant corolla lobe character. Seeds were collected every two days in $1 \mathrm{~m}$ wide concentric rings around the core, and were progeny tested in the greenhouse. The principal pollinator of $P$. drummondii was Battus philinor. This and other lepidopterans were scored for interplant flight distance. Data for three episodes of pollination and gene flow are presented in Figure 1. Each pollination episode was scored over several days 3 to 4 weeks prior to each seed collection. Since the seeds mature in 3 to 4 weeks, the amount and distribution of hybrids will be a function of the foraging behavior we observed. The pollinator flight distribution was highly leptokurtic, with most flights being $2 \mathrm{~m}$ or less. A small percentage of the flights exceeded 10 $\mathrm{m}$ (Fig. 1). The mean flight distance was ca. $2.75 \mathrm{~m}$. In contrast, the gene flow pattern was less leptokurtic, and had more events beyond $10 \mathrm{~m}$. Mean gene flow 

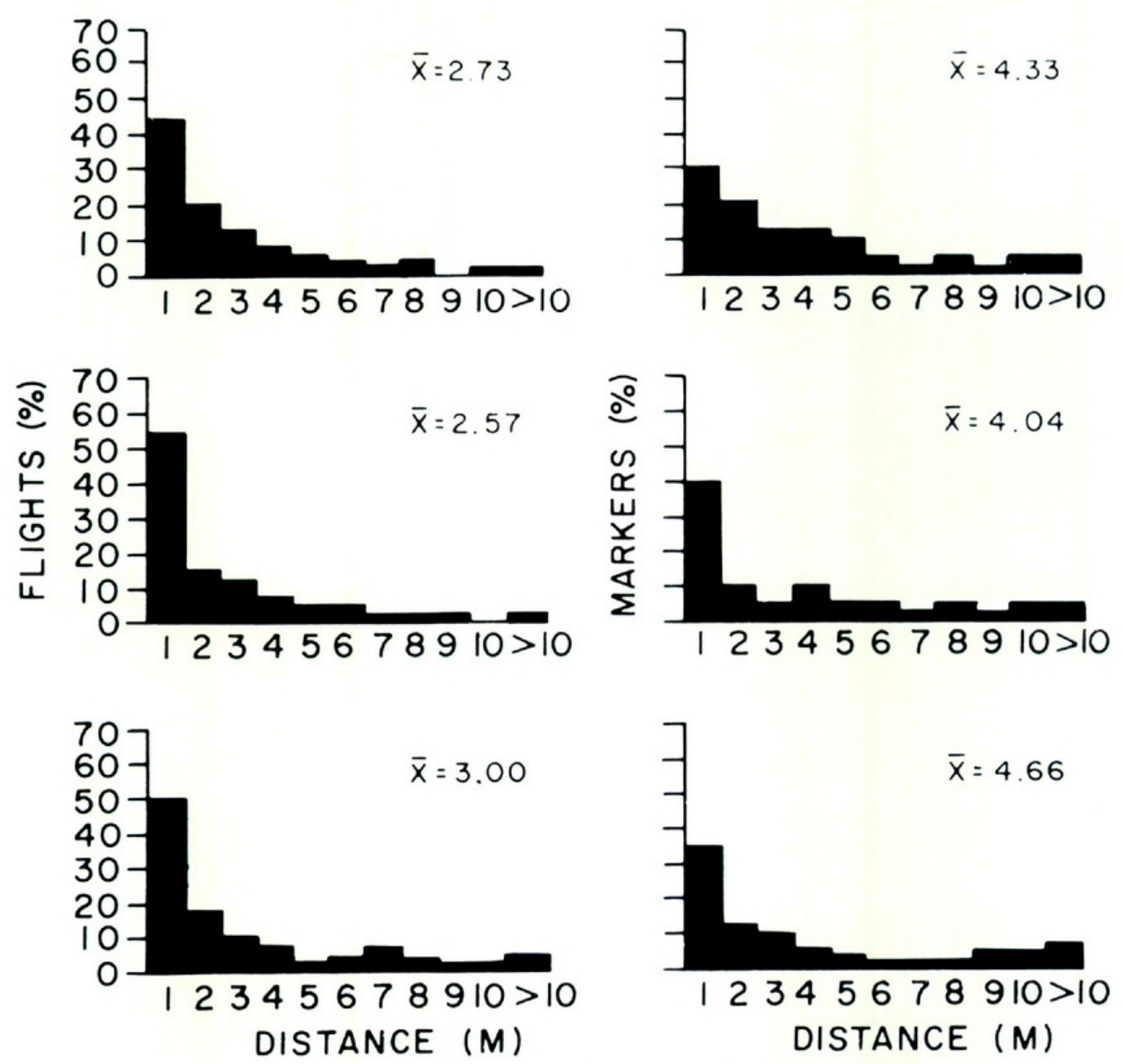

Figure 1. Pollinator flight distance and gene flow distance at three periods of the growing season in a population of Phlox drummondii (Gonzales, Texas).

distance was about $4.3 \mathrm{~m}$, which was about 1.5 times the mean flight distance. This difference must be due to pollen carry-over.

A disparity between pollinator flight and gene flow distributions also has been observed in Lupinus texensis by Schaal (1980). She placed 7 plants homozygous for an electrophoretic marker into a synthetic population of 91 plants lacking this marker. Bees were allowed to forage for 3 days and their flight distances were scored. Thereafter all plants were returned to the greenhouse, and seeds were collected subsequently from the field bee-exposed flowers. Mean pollinator flight distance was $0.97 \mathrm{~m}$ vs. $1.82 \mathrm{~m}$ for the gene flow distance. The level of kurtosis was significantly higher in the flight distribution. The differences in means and kurtosis are the result of pollen carry-over.

\section{Differential Crossability}

It is tempting to assume that parental distances are distributed as are the distances of pollen grains. However, pollen grains from all plants do not have an equal probability of effecting fertilization in a given plant. The self-incompatibility (S) locus may preclude certain types of crosses. Pollen which shares a self-compatibility allele with another plant is excluded from breeding with it (de Nettan- 
court, 1977). Given the richness of S-alleles in natural populations, plants sharing S-alleles are likely to be related. This means that in populations where seed dispersal is highly restricted, and thus where neighboring plants are often related, a distant pollen grain is more likely to effect fertilization than a pollen grain from a neighboring plant.

The success of pollen, or its fertilization ability, may be a function of the similarity of the pollen genotype to the stigma genotype. Pfahler (1965) analyzed the fertilization ability of maize pollen using pollen mixtures containing $50 \%$ pollen from each of two parents. The two pollen types are equally successful if $50 \%$ of the progeny have a marker from one parent. When pollen from a source related to the female was mixed with pollen from unrelated sources in various 2-way combinations, between $33 \%$ and $43 \%$ of the fertilizations involved the related pollen. Thus related pollen was at a disadvantage, and negative assortative mating ensued. Since self-pollen often is competitively inferior to outcross pollen in mixtures (cf. Mulcahy, 1975), it is likely that the disadvantage of related outcross pollen vis-à-vis unrelated pollen is a common phenomenon.

Given that pollen-pistil compatibility might vary with relatedness, might it also vary with distance in species with narrow seed and pollen dispersal? We sought the relationship between pollen-pistil compatibility and plant distance in Phlox drummondii. Pollen and seed dispersal in this species typically is a few meters or less, and populations display significant heterozygote deficiency relative to Hardy-Weinberg expectations (Levin, 1977). These observations suggest that populations undergo moderate inbreeding.

Phloxes were collected as seedlings along 35 m linear transects in each of 14 populations. The seedlings were grown to maturity in the greenhouse. Crosses were made within and between populations. Crossability was considered in terms of the spatial relationships of the pollen and egg parents which were known. On the average, pollen grain germination increased with distance up to $10 \mathrm{~m}$. Additional distances up to $35 \mathrm{~m}$ were not accompanied by overall changes in germination percentage. Pollen germination averaged about $17 \%$ with near-neighbor pollinations vs. ca. $20 \%$ with pollinations involving plants $10 \mathrm{~m}$ away or more. Pollen from parents in neighboring populations displayed germination rates similar to those found in intrapopulation crosses beyond $10 \mathrm{~m}$. Pollen from sources greater than $20 \mathrm{~km}$ away performed substantially below that of pollen from within populations or from neighboring populations, mean germination being ca. $19 \%$ and $14 \%$, respectively. Thus pollen germination rates are highest when mating plants are moderate distances apart.

The crossability of two plants depends not only on pollen-pistil compatibility, but also upon the vigor of the developing seed. The developing seed is sensitive to genetic disharmonies brought about by inbreeding. High levels of seed abortion following inbreeding are well known in numerous predominantly outcrossing species (Crumpacker, 1967; Franklin, 1970).

Of particular interest within the context of this discussion is whether abortion is dependent on the distance between mating plants. If relatedness is a function of distance, we would expect abortion levels between neighboring plants to be higher than that between plants several meters apart. In populations of Phlox drummondii, seed abortion decreased with interparent distances up to about 10 
$\mathrm{m}$, and remained at that level as distances increased to $35 \mathrm{~m}$. Abortion following crosses of $1 \mathrm{~m}$ or less averaged $18 \%$ vs. $14 \%$ following crosses of $10 \mathrm{~m}$ and more. It seems likely that higher abortion in the progeny of crosses between neighbors reflects their overall relatedness, because abortion levels increase substantially with self-fertilization. Crosses between neighboring populations did not yield lower abortion levels than that observed at interparent distances beyond $10 \mathrm{~m}$ within populations. Crosses between populations more than $20 \mathrm{~km}$ apart did yield significantly higher abortion rates (19\% vs. 14\%). Distance-dependent abortion rates also have been described within Picea glauca (Coles \& Fowler, 1976). Crosses between plants less than $100 \mathrm{~m}$ apart yielded $28 \%$ less sound seed than crosses at greater distances. Selfing produces little sound seed. Presumably some plants near each other were relatives, so that inbreeding varied as a function of distance.

Seed-set in plants is dependent upon pollen-pistil compatibility and seed viability. In Phlox drummondii, seed-set tends to increase as the distance between plants within a population increases. This pattern is evident across populations. Seed-set from crosses between near neighbors averages 53\% compared to $65 \%$ for crosses between plants at least $10 \mathrm{~m}$ apart. Crosses between neighboring populations have seed-sets similar to that of crosses between plants $20 \mathrm{~m}$ apart $(\overline{\mathrm{x}}=63 \%)$. However, crosses between populations more than $20 \mathrm{~km}$ apart yielded lower seed-set $(\overline{\mathrm{x}}=55 \%)$ than crosses between neighboring populations. Thus the general pattern is one of an intermediate optimum, more than a few meters and less than $20 \mathrm{~km}$.

Seed-set following crosses between parents separated by various distances has also been analyzed in Delphinium nelsonii (Price \& Waser, 1979). For the most part, $10 \mathrm{~m}$ crosses gave higher seed-set in the two study populations over two years than crosses over $1 \mathrm{~m}, 3 \mathrm{~m}, 30 \mathrm{~m}, 100 \mathrm{~m}$ and $1000 \mathrm{~m}$. The pattern of an intermediate optimum also has been described in Stylidium. In S. elongatum and $S$. confluens, the percentage seed-set was greater in crosses separated by 40 to $60 \mathrm{~km}$ than in crosses of smaller or greater distances (Banyard \& James, 1979). Since embryo abortion often follows self-fertilization in these species, it seems likely that reduced seed-sets in intrapopulation crosses were a manifestation of inbreeding depression. A decline in seed-set between "distant" populations in Delphinium and Stylidium may be due to genome incompatibility fostered by divergent local adaptations.

As we study fine scale crossing relationships in natural populations, it is evident that the facility with which plants interbreed is dependent on their spatial relationships which are correlated with their genetic relationships. On the average, neighboring plants in outcrossing species seem less likely to successfully interbreed than plants tens to hundreds of meters apart. As a consequence, the breeding structure of populations may be more open than we would imagine.

\section{DifFERENTIAL ViabiLity}

The breeding structure of populations needs to be considered in terms of the resulting standing crop as well as the zygote or seed population. As the breeding structure of the seed population is shaped by genotype-dependent mortality during development, so the breeding structure of the adult population is shaped by 
genotype-dependent mortality throughout the vegetative phase of the life cycle. In essence, there is a potential and realized breeding structure. The former describes the mating pattern, the latter integrates the mating pattern and mortality.

Products of outcrossing typically have higher viability than products of selfing during seed development and as established plants (Allard et al., 1968; Stern \& Roche, 1974; Janossy \& Lupton, 1976). In conifers the incidence of seed abortion (Koski, 1971, 1973; Birshir \& Pepper, 1978), and defective or slow growing seedlings (Franklin, 1970; Koski, 1973) is 2 to 5 times higher with selfing than with outcrossing. The genetic load per zygote averages more than 8 lethal equivalents in some species of Pinus and Pseudotsuga (Franklin, 1972; Sorensen, 1969; Koski, 1973). Although zygote populations of many species are often somewhat inbred, the level may diminish through time as a result of differential mortality. For example, in Eucalyptus pauciflora the average outcrossing rate for seeds is $63 \%$ compared to $76 \%$ for seedlings (Phillips \& Brown, 1977). Different outcrossing rates are seen even among seeds stored for different periods. In Eucalyptus delegatus, outcrossing rates in old seeds was $85 \%$ versus $66 \%$ in the most recent collection (Moran \& Brown, 1980).

Differences in seedling quality as a function of interplant distances have been found when sought. One component of seedling quality, epicotyl length was studied in the progeny of crosses of various distances in Picea glauca. Epicotyls of progeny of near-neighbor crosses were shorter than those from distantly spaced parents (Coles \& Fowler, 1976). These data suggest that neighboring plants were related, especially since the epicotyls of self-pollinated seedlings were $24 \%$ shorter than those from long-distance outcrosses. Differences in epicotyl length as a function of distance have obvious fitness implications in that the larger seedlings within a cohort usually have higher survivorship than the smaller ones (Harper, 1977).

The effects of interparent distance on seedling survivorship have been described in Delphinium nelsonii (Price \& Waser, 1979). Seedlings from crosses between plants $10 \mathrm{~m}$ apart had higher survivorship in the native sites than seedlings from crosses between plants $1 \mathrm{~m}, 100 \mathrm{~m}$, and $1000 \mathrm{~m}$ apart, respectively. Self-seedlings had the lowest survivorship. Price \& Waser conclude that seedlings from crosses between neighboring plants may be suffering inbreeding depression, whereas the seedlings of wide crosses may be suffering genomic incompatibility.

Survivorship within a cohort is most likely to be genotype-dependent with mixed selfing and outcrossing. In species of inbreeding annuals, it is common to find an excess of heterozygotes relative to expectations based on the mating system (Allard et al., 1968; Clegg et al., 1978). Comparisons of seedlings and adult genotypes from natural populations of Avena barbata showed that heterozygotes at one of 3 esterase loci had about a $30 \%$ advantage over the homozygotes (Clegg \& Allard, 1973). In Avena sativa, heterozygotes for two loci governing crown rust reaction had a $50 \%$ advantage over homozygotes (Fatunla \& Frey, 1980). On the other hand, no substantial viability advantage was found in single or multilocus heterozygotes in experimental barley populations (Clegg et al., 1978). Genotype frequencies in parents and progeny have been analyzed in $\mathbf{E u}$ calyptus pauciflora (Phillips \& Brown, 1977) and E. delegatensis (Moran \& 
Brown, 1980). Heterozygotes appear to have about a $20 \%$ advantage in the former, and a $50 \%$ advantage in the latter. In perennials changes in heterozygosity through time may be inferred from genotype frequencies in different age classes all sampled at one time. Using this approach, Schaal \& Levin (1976) found a substantial increase in heterozygosity through time in Liatris cylindracea. Differential survivorship in favor of heterozygotes effectively opens the realized breeding structure of populations because survivors are weighted in favor of the progeny of unrelated plants.

\section{SeEd DisPersal}

Distributions of seed dispersal distances have been described for numerous species with various adaptations for dispersal (cf. Levin \& Kerster, 1974; Levin, 1979). For the most part, seeds remain in the vicinity of the seed source. The long-distance component of seed dispersal distributions is poorly understood and difficult to document. It is likely that our impressions of seed dispersal are too conservative owing to our ignorance of the dispersal curve tail (Grant, 1980).

Seed dispersal typically is measured in terms of absolute distance. However, a mean dispersal distance of $25 \mathrm{~m}$ in a population of mesophytic climax tree species does not have the same implications as it does for a small prairie herb. For the tree, $25 \mathrm{~m}$ would be only 2 or 3 plant diameters (canopies) away, whereas for the herb $25 \mathrm{~m}$ would be hundreds of plants from the source. Accordingly, parents and offspring would be near-neighbors in the case of the tree, but widely spaced in the case of the herb. It also follows that half-sibs borne on a single plants will be near-neighbors in the case of the tree, but well dispersed in the case of the herb. Near-neighbor pollination in the former would then result in inbreeding, whereas in the latter it would not. Also, it follows that the gene pool of the tree species would be little homogenized by $25 \mathrm{~m}$ dispersal whereas that of the herb would be well homogenized. We may conclude that in this example seed dispersal or seed-mediated gene flow effectively is much greater in the herb than the tree.

The numbers of juxtaposed plant canopies over which seeds are dispersed is easily estimated. Phlox pilosa seeds are scattered by capsule dehiscence an average of $1.2 \mathrm{~m}$ with a maximum of $3.6 \mathrm{~m}$ (Levin \& Kerster, 1968). The diameter of a mature plant in a typical site is about $3 \mathrm{dm}$. Accordingly, seeds are dispersed an average of 4 plant diameters and a maximum of 10 diameters. Seeds of Liatris aspera are dispersed an average $2.5 \mathrm{~m}$ with a maximum of $9 \mathrm{~m}$ (Levin \& Kerster, 1969). The diameter of a robust adult is about $20 \mathrm{dm}$. Accordingly, seeds are dispersed an average of 12 plant diameters and as far as 45 diameters. In Eucalyptus regnans, wind-borne seeds travel a mean distance of about $40 \mathrm{~m}$ and as far as $125 \mathrm{~m}$ (Gilbert, 1958). With plant diameters of $8 \mathrm{~m}$, seeds are being dispersed an average of 5 plant diameters and as far as 15 diameters. These examples are representative of late successional plants and point to the effectively restricted distribution of seeds therein. Mean seed dispersal distances for weedy plants with a well-developed plumose pappus are not available. However, from Sheldon \& Burrows's (1973) calculations of dispersability based upon propagule's terminal velocity and resistance coefficients, we may infer that in strong winds seeds of 
such weeds as Cirsium arvense and Sonchus arvensis are transported an average of 20 plant diameters. Plumed propagules of Salix repens and Populus tremula also may be carried an average of 15 diameters or more. The so-called weedier plants thus are "placing" their offspring farther away than are the late successional species.

The distribution of seed relative to a source may be altered by distance- and density-responsive seed predators as proposed by Janzen (1970). He argued that "no matter how large the seed crop in a given year, or how far the seed from the parent, density-responsive predators will pursue seeds and seedlings until their density is so low that search is no longer profitable." He also postulated that "if seeds are placed or planted at various distances from a parent tree at low density . . . , their survival to well developed sapling stages should increase with distance from the parent." Janzen's postulates have received support from seed predation patterns in Sterculia apatula (Janzen, 1972), Scheelea rostrata (Wilson \& Janzen, 1972), Juglans nigra (Stapanian \& Smith, 1978), Andira inermis (Janzen et al., 1976), and Datura discolor (O'Dowd \& Hay, 1980), and seedling mortality patterns in Casearia nitida (Howe \& Primack, 1975) and Casearia corymbosa (Howe, 1977). Density-dependent and proximity-dependent predation introduce a differential between potential seed dispersal and actual seed dispersal, the mean and variance of the latter being greater. Since predation tends to increase distance between parents and offspring, and between half-sibs, the result is an opening of the breeding structure of populations.

\section{Interpopulation Gene Flow}

The extent of interpopulation gene exchange in nature is unknown. On the other hand, plant breeders have determined distances sufficient to preclude interpopulation contamination of varieties. In many outcrossing crops, more than $5 \%$ of the seeds will be hybrid if the distance between populations is about $10 \mathrm{~m}$; and more than $1 \%$ of the seeds will be hybrid if the distance is about $500 \mathrm{~m}$ (Kernick, 1961; International Crop Improvement Association, 1963). We might be tempted to assume that gene flow in crops is representative of that in natural populations. However, there are several considerations which suggest that gene flow between natural populations may be higher than that in crops over the same distance. First, there is the matter of population size. Natural populations typically are smaller and more patchy in their structure than crop plots. The level of interpopulation hybridization is a function of population size or varietal mass, so that hybridization between populations will increase as population size declines (Fryxell, 1956; Bateman, 1947; Crane \& Mather, 1943; Williams \& Evans, 1935). Another consideration is the spatial relationships of populations. Plant breeders employ a donor population and one to several recipient populations. All pollen can be traced to that donor population. In nature, a population may receive pollen from several neighboring populations. Even if the levels were low from each source, they are additive, and the sum might have a considerable impact on the genetic structure of the recipient population. Finally, there is the matter of the pollinator. Most animal-pollinated crop plants are serviced primarily by honeybees, whose foraging area is considerably less than other bees and lepidopter- 
ans (Heinrich, 1975; Free, 1970). Accordingly, hybridization is lower than might be the case were the same plants subjected to natural pollinators.

The extent to which gene flow fosters the convergence of populations or restricts their divergence depends not only on the frequency of hybridization but also upon the adaptedness of hybrids. The more fit the hybrids the greater the importance of each hybridization event. Are interpopulation hybrids inferior or superior to indigenous plants? In predominantly outbreeding crop species, the vigor and fecundity of hybrids typically increase as the genetic distance between parental strains increases until some critical level of divergence is reached when interactions at a few loci counterbalance the effect of heterozygosity. In maize, heterosis is a positive function of the level of divergence of strains except for the most divergent ones (Moll et al., 1965). In Nicotiana (Matzinger \& Wernsman, 1967) and Gossypium (Mariani \& Avieli, 1973), heterosis increases with divergence to the level of related species.

In natural population systems, maximum heterosis also is associated with moderate levels of divergence. Heterosis has been documented in interracial crosses of Norway spruce (Nilsson, 1974), Douglas fir (Orr-Ewing, 1969), and loblolly pine (Woessner, 1972; Owino \& Zobel, 1977). Greater heterosis and higher fertility were obtained in the progeny of crosses between Liriodendron tulipifera of different populations (often only a few miles apart) than in crosses within the same population (Carpenter \& Guard, 1950). Heterosis in Mimulus is best developed in hybrids between populations which have undergone moderate degrees of divergence regardless of their geographical relationships (Vickery, 1978). Beltran \& James (1974) demonstated heterosis in hybrids between chromosomally homozygous populations of Isotoma petraea, the more inbred the populations the greater the vigor of their hybrids. No correlation was found between heterosis and the level of population divergence. The Isotoma study is of particular interest because it shows that the genetic structure of populations, as shaped by population size and breeding structure, affects the relative quality of distant pollen parents.

Our knowledge of interpopulation hybrids is based principally upon crosses between populations tens to hundreds of miles apart, and upon performance trials in greenhouses, gardens, or plantations. Of principal concern here are hybrids between neighboring populations or those within pollination range, and how those hybrids would fare in natural populations. Neighboring populations may be well differentiated as a result of selective differentials or random drift. If populations are different by virtue of differential selection and hybrids are intermediate to their parents, then interpopulation hybrids may be ill-fit in either population; it is unlikely they will be better adapted than local residents. On the other hand, if populations have small effective sizes, have diverged as a result of stochastic processes, and are genetically depauperate, then interpopulation hybrids may be superior (heterotic) to local residents in both the egg and pollen parent populations.

\section{Genetic Differentiation}

In practice we estimate gene flow in plants from the distributions of pollen and seeds, or from the movements of pollen and seed dispersers. We use dispersal 
in one form or another to estimate gene flow. Whereas dispersal of pollen and seeds has some general predictive value with regard to gene flow, dispersal per se does not guarantee gene flow. This point recently was elaborated upon by Endler $(1977,1979)$ with respect to animals. He concludes that dispersal overestimates gene flow because of the complexities of animal behavior and their life history attributes. In the case of plants I have reached the opposite conclusion. Estimates of gene flow based upon dispersal of pollinators, pollen grains, and seeds tend to underestimate actual gene flow distances because they do not take into consideration pollen carry-over and flight directionality, proximity-dependent cross-compatibility and seed-set, and proximity- and density-dependent seed predation and seedling survivorship, seed pools, genotype-dependent survivorship, and the fitness of interpopulation hybrids. The implications of wider gene dispersal are best understood within the framework of breeding structure and selection models which provide numerical and spatial scales upon which patterns of gene flow may be interpreted.

The breeding structure of populations may be considered in terms of Wright's $(1940,1943,1946,1951)$ neighborhood model. The neighborhood is the area from which any two parents could have come with equal probability. The effective size of a neighborhood is equivalent to the number of reproducing individuals in a circle whose radius is equivalent to twice the standard deviation of the gene dispersal distance (Wright, 1946). Strictly speaking this circle includes $87 \%$ of the parents of individuals at its center. The neighborhood size in a plant with pollen and seed dispersal may be described as $\mathrm{N}_{\mathrm{e}}=6.3 \operatorname{dr}\left(\Sigma \mathrm{p}_{\mathrm{i}}{ }^{2} / 2 \mathrm{~N}_{\mathrm{p}}+\Sigma \mathrm{s}_{\mathrm{i}}{ }^{2} / \mathrm{N}_{\mathrm{s}}\right)$ where $p$ refers to pollen dispersal distance, $N_{p}$ number of pollen dispersal observations, $s$ the seed dispersal distance, $\mathrm{N}_{\mathrm{s}}$ the number of seed dispersal observations, and $r$ the proportion of outcross progeny (Levin \& Kerster, 1969). The area of a neighborhood is $\mathrm{N}_{\mathrm{e}} / \mathrm{d}$, where $\mathrm{d}$ is the genetically effective density. Genetically effective density is approximately the density of flowering plants. The neighborhood describes the scale of gene flow and thus sets the lower limit on the area that can respond to spatially defined disruptive selection (Slatkin, 1973; May et al., 1975; Endler, 1977).

Estimates of neighborhood size and area for several representative herbs and trees are enumerated in Tables 2 and 3. Neighborhood sizes vary from 5 in the facultatively cleistogamic Lithospermum caroliniense to 547 in Viola pedata. Neighborhood areas also vary widely among species, ranging from less than 20 $\mathrm{m}^{2}$ in Viola blanda and Phlox pilosa to over $30,000 \mathrm{~m}^{2}$ in Pinus elliottii. There is also considerable variation within species. The neighborhood sizes of herbs and trees fall within the same range, but the neighborhood areas of trees are considerably larger. The size of the neighborhood determines the level of inbreeding and penchant for genetic drift between sectors of population. For most species in Table 2, the size of the neighborhood is sufficient $(>50)$ to preclude substantial differentiation via genetic drift within a continuous population (Wright, 1943). These values are calculated from dispersal data alone and thus are apt to be underestimates of actual neighborhood sizes.

The area of neighborhoods in plants, especially herbs, is sufficiently small to permit marked differentiation in response to selection over short to moderate distances. If mean gene flow distances were greater than that of dispersal, the 
TABLE 2. Neighborhood size and gene flow-selection balance in herbs.

\begin{tabular}{|c|c|c|c|c|c|c|c|}
\hline \multirow[b]{2}{*}{ Species } & \multirow[b]{2}{*}{$N_{e}$} & \multirow[b]{2}{*}{$l^{\mathrm{a}}$} & \multirow[b]{2}{*}{$l_{c}^{\mathrm{b}}$} & \multicolumn{2}{|c|}{ Cline width ${ }^{c}$} & \multirow{2}{*}{$\begin{array}{l}\text { Coeffi- } \\
\text { cient } \\
\text { of } \\
\text { Selec- } \\
\text { tion }^{\mathrm{d}}\end{array}$} & \multirow[b]{2}{*}{ Reference } \\
\hline & & & & $\begin{array}{c}\Delta= \\
0.1 \mathrm{~m}\end{array}$ & $\begin{array}{c}\Delta= \\
1000 \mathrm{~m}\end{array}$ & & \\
\hline Phlox pilosa & $75-282$ & $1.6 \mathrm{~m}$ & $5.1 \mathrm{~m}$ & $12.5 \mathrm{~m}$ & $71.1 \mathrm{~m}$ & 0.03 & Levin \& Kerster, 1968 \\
\hline Liatris aspera & $30-191$ & $1.5 \mathrm{~m}$ & $4.7 \mathrm{~m}$ & $11.5 \mathrm{~m}$ & $67.4 \mathrm{~m}$ & 0.02 & Levin \& Kerster, 1969 \\
\hline Liatris cylindracea & 165 & $2.3 \mathrm{~m}$ & $7.3 \mathrm{~m}$ & $17.9 \mathrm{~m}$ & $90.8 \mathrm{~m}$ & 0.05 & Schaal \& Levin, 1978 \\
\hline Viola pedata & $205-547$ & $2.5 \mathrm{~m}$ & $7.9 \mathrm{~m}$ & $19.4 \mathrm{~m}$ & $95.2 \mathrm{~m}$ & 0.06 & Beattie \& Culver, 1979 \\
\hline $\begin{array}{l}\text { Viola pensylvanica } \\
\text { Lithospermum caroli- }\end{array}$ & 310 & $3.6 \mathrm{~m}$ & $8.2 \mathrm{~m}$ & $20.1 \mathrm{~m}$ & $97.6 \mathrm{~m}$ & 0.07 & Beattie \& Culver, 1979 \\
\hline niense & 5 & $1.4 \mathrm{~m}$ & $4.5 \mathrm{~m}$ & $11.0 \mathrm{~m}$ & $65.4 \mathrm{~m}$ & 0.03 & Kerster \& Levin, 1968 \\
\hline
\end{tabular}

a $l=$ square root of mean squared dispersal distance.

b $l_{c}=$ characteristic length scale of variation of gene frequencies; $s=0.10$.

c $s=0.10 ; \Delta$ refers to width of environment transition.

${ }^{d}$ For gene substitution over $30 \mathrm{~m}$.

neighborhood area would increase. Then there would be less isolation by distance within and between populations, and less potential for selective differentiation over short distances, than would be possible with the areas enumerated in Tables 2 and 3.

The relationship between gene flow and selection in shaping local variation patterns in a heterogeneous environment and the spatial scale of such variation is best considered in terms of a one-dimensional gene flow scale $l$, the square root of the mean squared dispersal distance, rather than neighborhood area (Fisher, 1950; Slatkin, 1973; Endler, 1977). The gene flow distance, $l$, is related to the neighborhood radius by $\mathrm{r}=l \sqrt{2}$. The smaller that $l$ is the greater the isolation by distance between two subpopulations, and the more rapidly and fully these aggregates may respond to local selective differentials. Knowing $l$, we may calculate the minimum distance over which a population may respond to selection, assuming an abrupt selective change between adjacent environments as in Endler's (1977) ecotone model. This is referred to as the characteristic scale length

TABLE 3. Neighborhood size and gene flow-selection balance in trees.

\begin{tabular}{|c|c|c|c|c|c|c|c|}
\hline \multirow[b]{2}{*}{ Species } & \multirow[b]{2}{*}{$N_{e}$} & \multirow[b]{2}{*}{$l^{\mathrm{a}}$} & \multirow[b]{2}{*}{$l_{c}^{\mathrm{b}}$} & \multicolumn{2}{|c|}{ Cline width ${ }^{\mathrm{c}}$} & \multirow{2}{*}{$\begin{array}{l}\text { Coeffi- } \\
\text { cient } \\
\text { of } \\
\text { Selec- } \\
\text { tion }^{\mathrm{d}}\end{array}$} & \multirow[b]{2}{*}{ Reference } \\
\hline & & & & $\begin{array}{c}\Delta= \\
0.1 \mathrm{~m}\end{array}$ & $\begin{array}{c}\Delta= \\
1000 \mathrm{~m}\end{array}$ & & \\
\hline Pinus cembroides & 11 & $17.0 \mathrm{~m}$ & $53.8 \mathrm{~m}$ & $131.8 \mathrm{~m}$ & $342.0 \mathrm{~m}$ & 0.02 & J. Wright, 1953 \\
\hline Pinus elliottii & 365 & $67.8 \mathrm{~m}$ & $214.4 \mathrm{~m}$ & $525.3 \mathrm{~m}$ & $959.7 \mathrm{~m}$ & 0.25 & Wang et al., 1960 \\
\hline Cedrus atlantica & 207 & $74.3 \mathrm{~m}$ & $234.9 \mathrm{~m}$ & $575.5 \mathrm{~m}$ & $911.4 \mathrm{~m}$ & 0.31 & J. Wright, 1953 \\
\hline Pseudotsuga taxifolia & 26 & $18.8 \mathrm{~m}$ & $59.4 \mathrm{~m}$ & $145.5 \mathrm{~m}$ & $365.4 \mathrm{~m}$ & 0.02 & J. Wright, 1953 \\
\hline
\end{tabular}

a $l=$ square root of mean squared dispersal distance.

b $l_{\mathrm{c}}=$ characteristic length scale of variation of gene frequencies; $s=0.10$.

${ }^{c} s=0.10 ; \Delta$ refers to width of environment transition.

${ }^{d}$ For gene substitution over $300 \mathrm{~m}$. 
of variation of gene frequencies $\left(l_{c}\right)$ and is defined as $l_{c}=l / s$, where $s$ is the maximum difference in fitness between homozygotes in two environments (Slatkin, 1973). Regardless of the spatial heterogeneity in selection pressures, gene frequencies would not vary significantly over a distance less than this length. If the environment changes on a scale less than this length, gene frequencies will respond to selection intensities averaged over the characteristic length. When the scale of variation in the environment is greater than this length, populations can respond to a heterogeneous environment and differentiate into distinctive units with clines between them (May et al., 1975; Endler, 1977).

The characteristic scale lengths, assuming $s=0.10$, for the plants under consideration vary from $4.7 \mathrm{~m}$ for Liatris aspera to $234 \mathrm{~m}$ for Cedrus atlantica (Tables 2 and 3 ). If the selective differential between the environments is less, the distances would be greater and vice versa. As we might expect, populations of herbs are better able to respond to local environmental heterogeneity than trees. Were the intensity of selection reduced by an order of magnitude, the characteristic scale length would increase roughly 3 times. If the mean gene flow distance were twice the dispersal distance ( $l$ in Tables 2 and 3), then the characteristic scale lengths shown in Tables 2 and 3 would have to be doubled.

Consider next the width of clines between two habitat types which are juxtaposed, so that the transition occurs over a very short distance, less than the characteristic scale length. Suppose that genotypes AA, Aa, and aa have fitness of $1+s, 1$ and $1-s$, respectively, in one habitat, and $1-s, 1$, and $1+s$, respectively, in the other. The width of a cline from $\mathrm{p}=1$ to $\mathrm{p}=0$ is $2.45 l_{c}$ (May et al., 1975). Using 0.10 as the value of $s$ (as above), we find that the width of clines varies from 11 to $20 \mathrm{~m}$ for herbs (Table 2) and from 132 to $575 \mathrm{~m}$ for trees (Table 3). It is evident that marked differentiation, in this case gene substitution, can occur over relatively short distances in response to moderate selective differentials. This is the consequence of restricted gene flow. If the actual gene flow distances were twice those described ( $l$ in Tables 2 and 3), then the width of the cline would double.

The transition between environments may be gradual instead of abrupt. Suppose that one homozygote is best fit for one environment and the other homozygote the other, that the fitnesses of homozygotes varied over a $1000 \mathrm{~m}$ gradient, and that the fitness relationships are as given in the previous example. The width of the cline is $2.40\left(l_{c}{ }^{2} \Delta\right)^{1 / 3}$ where $\Delta$ is the transition distance over which both homozygote fitnesses are changing relative to one another (May et al., 1975). The width for the herbs is between 71 and $98 \mathrm{~m}$ (Table 2), and for the trees is between 342 and $960 \mathrm{~m}$ (Table 3). This illustration shows that substantial differentiation may occur over moderate distances along environmental gradients. Were the actual gene flow distances twice those inferred from dispersal distances, the clines would be twice as wide.

Finally let us ask the intensity of selection that would be necessary to bring about gene substitution ( $\mathrm{p}=1.0$ to $\mathrm{p}=0$ ) over a span of $30 \mathrm{~m}$ for herbs and 300 $\mathrm{m}$ for trees. The value of $s$ may be estimated from the following relationship: maximum slope of gene frequencies $\sim \sqrt{\mathrm{s} / 3 l}$, where the slope is the difference in gene frequencies/distance and $l$ is the root mean square of the migration distance as above (Slatkin \& Maruyama, 1975). The selection coefficients necessary to 
bring about gene substitution over $30 \mathrm{~m}$ in herbs are surprisingly small, less than .07 (Table 2). If the actual gene flow distances were greater than dispersal distances, the intensity of selection necessary for gene substitution would be greater. The selection coefficient necessary to bring about gene substitution over $300 \mathrm{~m}$ in trees is weak in some species and strong in others (Table 3). If the actual gene flow distances were greater than dispersal suggests, substitution would not be possible in Cedrus atlantica and Pinus elliottii.

The spread of an advantageous gene across populations also is dependent upon gene flow. It is intuitively obvious that the greater the distances over which genes move per generation the more rapid the spread of the advantageous gene. Fisher (1937) found that the advance of advantageous genes or velocity of the wave of gene increase along a linear habitat can be described as $v=\sigma(2 \mathrm{~m})$, where $\sigma$ is the standard deviation for gene flow distance and $m$ is the selective advantage. The standard deviation for the plant species considered earlier may be obtained from Tables 2 and 3, recognizing that the gene flow distance $l=2 \sigma$. The spread of an advantageous gene in Phlox pilosa, assuming that the selective advantage is $s=0.10$, is $0.16 \mathrm{~m}$ per generation. In Cedrus atlantica, the rate is $7.4 \mathrm{~m}$ per generation. Even if the selective advantage is large the spread is slow. If $s=0.5$, the rate of spread is still only $0.8 \mathrm{~m}$ per generation in Phlox and 37 $\mathrm{m}$ in Cedrus. The progress of the advantageous gene would be at least four times greater in a two-dimensional population with the same gene flow characteristics (Wright, 1969).

In the case of a linear array of discontinuous populations, the advantageous genes would progress in a wavelike fashion, with the velocity being a function of interpopulation gene flow and time to fixation within populations (Slatkin, 1976). The velocity of the wave of an advantageous gene may be estimated from the tabulations of Slatkin (1976). Consider a rather realistic set of circumstances in which populations are $1 \mathrm{~km}$ apart, where the population size $(\mathrm{N})$ equals 500 , adjacent populations exchange 1 individual per generation $(\mathrm{m}=1)$, and the advantage of a gene is $10 \%$. Under these circumstances, the rate of spread is about $20 \mathrm{~m}$ per generation. If gene flow were reduced by an order of magnitude $(\mathrm{m}=$ 0.1 ), the velocity would be about $11 \mathrm{~m}$ per generation.

Although gene exchange is most likely to occur between adjacent populations, there may be some between distant populations. These long-distance events would substantially increase the rate of spread of an advantageous gene. Returning to a linear array of populations and the tabulations of Slatkin (1976), and assuming that on the average 0.01 individual moves between populations 10 steps apart with populations of 500 and a selective advantage of $10 \%$, the rate of spread would be about $30 \mathrm{~m}$ per generation. This compares with $20 \mathrm{~m}$ per generation with gene flow between adjacent populations.

Models of gene migration in a one-dimensional array pertain to population systems distributed along rivers, shorelines, and other such linear habitats. Most plant population systems are distributed in two dimensions. The rate of spread of an advantageous gene in a two-dimensional array has not been described. However, it will be greater than in a one-dimensional array because there are more pathways over which a gene could move between populations (Slatkin, 1976). The rate of spread is determined primarily by the lag time associated with 
the movement of genes between populations, i.e., the time between gene entry and its attainment of a frequency such that it might be transported by a migrant (seed or pollen). Let us assume that in a two-dimensional array the level of gene exchange between populations increases by a factor of two, so that there are 2 migrants per generation between populations of $500(s=0.10)$. The rate of spread of an advantageous gene will be $23 \mathrm{~m}$ per generation compared to $20 \mathrm{~m}$ when there was only 1 migrant per generation. If the number of migrants is doubled in the aforementioned model of gene exchange between populations 10 steps removed (from 0.01 to 0.02 individual per generation), the rate of spread increases from $30 \mathrm{~m}$ per generation to $52 \mathrm{~m}$. If the number of migrants increases by a factor of 5 due to 2-dimensional gene exchange, the rate of spread increases to $86 \mathrm{~m}$ per generation. The progress of an advantageous gene through a population system remains moderate even with very liberal gene-flow estimates.

Depending upon whether a plant was predominantly selfing or outcrossing and on the means of seed dispersal, the wave of advance of a beneficial gene at high frequency probably would range from less than $5 \mathrm{~m}$ to more than $50 \mathrm{~m}$ per generation. At these rates a beneficial gene would not have time to dominate much beyond the region in which it originated. Using $25 \mathrm{~m}$ per generation for illustrative purposes, it would take 4000 years for a high frequency wave to move $100 \mathrm{~km}$ in an annual plant. Even if the rate were $100 \mathrm{~m}$ per generation, it would take 1000 years for a wave to cover this distance or over an area about 10,000 $\mathrm{km}^{2}$. This constitutes only a small portion of the range of most species. The rate of spread will be even slower in perennials, because the rate is measured in terms of distance per generation. The rate of spread in a short-lived perennial herb (generation time of 10 years) would be one-tenth that described, so that the range of distances per year would range from less than 0.5 to around $5 \mathrm{~m}$. For a longlived perennial, the rate would be reduced by an additional $50 \%$ or more. Clearly, with the biological processes we are envisioning, novel adaptive mutations originating in one population cannot rise to prevalence throughout a significant portion of a species range.

In summary, I have argued that estimates of gene flow within and among populations which are based upon the movement of pollinators, pollen, and seeds tend to be too small. On the other hand, the scale of dispersal is so small that even if gene flow distances were twice those of dispersal, differentiation within populations under moderate disruptive selection pressure, and interpopulation divergence with very weak selective differentials would still be possible. Indeed populations more than a few kilometers apart may be completely isolated by distance and thus free to diverge along avenues independent of those taken by other populations. Gene flow appears so restricted that novel adaptive mutations would be confined to relatively small portions of species ranges.

The view of Ehrlich \& Raven (1969) that gene flow is not a prime integrating force within species still seems valid. Indeed, if cohesion does occur as a consequence of gene exchange, ostensibly it is within continuous subpopulations, discontinuous subpopulations, or tightly knit clusters of neighboring populations. These narrowly circumscribed ensembles thus are the effective units of evolution.

Literature Cited

Allard, R. W., S. K. JaIn \& P. L. Workman. 1968. The genetics of inbreeding species. Advances Genet. 14: 55-131. 
BAKer, H. G. \& P. D. Hurd. 1968. Intrafloral ecology. Annual Rev. Entomol. 13: 385-414.

BANYARD, B. J. \& S. H. James. 1979. Biosystematic studies in the Stylidium crassifolium species complex (Stylidae). Austral. J. Bot. 27: 27-37.

Bateman, A. J. 1947. Contamination of seed crops. I. Insect pollination. J. Genet. 48: 257-275.

Beattie, A. J. \& D. C. Culver. 1979. Neighborhood size in Viola. Evolution 33: 1225-1229.

Beltran, I. C. \& S. H. James. 1974. Complex hybridity in Isotoma petraea. IV. Heterosis in interpopulational hybrids. Austral. J. Bot. 22: 251-264.

Birshir, J. \& W. D. Pepper. 1978. Estimation of number of embryonic lethal alleles in conifers. I. Self-pollinated seed. Silvae Genet. 27: 50-54.

Carpenter, I. W. \& A. T. Guard. 1950. Some effects of cross-pollination on seed production and hybrid vigor of tuliptrees. J. Forest. 48: 852-855.

Clegg, M. T. \& R. W. Allard. 1973. Viability and fecundity selection in the slender wild oat, Avena barbata $\mathrm{L}$. Science 181: 667-668.

- A. L. Kahler \& R. W. Allard. 1978. Estimation of life cycle components of selection in an experimental plant population. Genetics 89: 765-792.

Coles, J. F. \& D. P. Fowler. 1976. Inbreeding in neighboring trees in two white spruce populations. Silvae Genet. 25: 29-34.

Crane, M. B. \& K. Mather. 1943. The natural cross-pollination of crop plants with particular reference to the radish. J. Appl. Biol. 30: 301-308.

Crumpacker, D. W. 1967. Genetic loads in maize (Zea mays L.) and other cross-fertilized plants and animals. Evol. Biol. 1: 306-424.

Ehrlich, P. R. \& P. H. Raven. 1969. Differentiation of populations. Science 165: 1228-1232.

Endle R, J. A. 1977. Geographic Variation, Speciation, and Clines. Princeton Univ. Press, Princeton, New Jersey.

- 1979. Gene flow and life history patterns. Genetics 93: 263-284.

FAtUnla, T. \& K. J. Frey. 1980. Analysis of genetic changes in radiated and non-radiated bulk oat (Avena sativa L.) populations. Theor. Appl. Genet. 56: 199-202.

Fischer, R. A. 1937. The wave of advance of advantageous genes. Ann. Eugen. 7: 355-369.

. 1950. Gene frequencies in a cline determined by selection and diffusion. Biometrics 6: $353-$ 361.

Franklin, E. C. 1970. Survey of mutant forms and inbreeding depression in species of the family Pinaceae. Southeast Forest Expt. Sta. USDA For. Serv. Res. Pap. SE-61:1-21.

- 1972. Genetic load in loblolly pine. Amer. Naturalist 106: 262-265.

FreE, J. B. 1970. Insect Pollination of Crops. Academic Press, New York.

FrYXELl, P. A. 1956. Effect of varietal mass on the percentage of outcrossing in Gossypium hirsutum. J. Hered. 57: 299-301.

Gilbert, J. M. 1958. Forest succession in the Florentine Valley, Tasmania. Proc. Royal Soc. Tasmania 93: 129-151.

Gill, F. B. \& L. L. Wolf. 1977. Nonrandom foraging by sunbirds in patchy environment. Ecology 58: $1284-1296$.

Grant, V. 1980. Gene flow and the homogeneity of species populations. Biol. Zbl. 99: 157-169.

Harper, J. L. 1977. Population Biology of Plants. Academic Press, New York.

Harrington, J. F. 1972. Seed storage and longevity. Pp. 145-245, in T. T. Kozlowski (editor), Seed Biology. Vol. 3. Academic Press, New York.

Heinrich, B. 1975. Energetics of pollination. Ann. Rev. Ecol. Syst. 6: 139-170.

1976. The foraging specializations of individual bumblebees. Ecol. Monogr. 46: 105-128.

_. 1979a. "Majoring" and "minoring" by foraging bumblebees, Bombus vagans: An experimental analysis. Ecology 60: 245-255.

. 1979b. Resource heterogeneity and patterns of movement in foraging bumblebees. Oecologia 40: $235-245$.

HowE, H. F. 1977. Bird activity and seed dispersal of a tropical tree. Ecology 58: 539-550.

— \& R. Primack. 1975. Differential seed dispersal by birds of the tree Casearia nitida (Flacourtiaceae). Biotropica 7: 278-283.

International Crop Improvement Association. 1963. Minimum Seed Certification Standards. Publ. 20.

Janossy, A. \& F. G. H. Lupton (editors). 1976. Heterosis in Plant Breeding. Elsevier, New York. JANZEN, D. H. 1970. Herbivores and the number of tree species in tropical American forests. Amer. Naturalist 104: 501-528.

. 1972. Escape in space by Sterculia apetala seeds from the bug Dysdercus fasciatus in a Costa Rican deciduous forest. Ecology 53: 350-361.

, G. A. Miller, J. Hackforth-James, C. M. Pond, K. Hooper \& D. P. Janos. 1976. Two Costa Rican bat-generated seed shadows of Andira inermis (Leguminosae). Ecology 57: 10681075.

Kernick, M. D. 1961. Seed production of specific crops. Pp. 181-547, in Agricultural and Horticultural Seeds. FAO Agricultural Studies No. 55. 
Kerster, H. W. \& D. A. LeVIN. 1968. Neighborhood size in Lithospermum caroliniense. Genetics 60: $577-587$

Koski, V. 1971. Embryonic lethals of Picea abies and Pinus sylvestris. Comm. Inst. For. Fenn. 75: $1-30$.

. 1973. On self-pollination, genetic load, and subsequent inbreeding in some conifers. Comm. Inst. For. Fenn. 78: 1-42.

LEvin, D. A. 1977. The organization of genetic diversity in Phlox drummondii. Evolution 31: 477494.

1979. The nature of plant species. Science 204: 381-384.

\& H. W. Kerster. 1968. Local gene dispersal in Phlox pilosa. Evolution 22: 130-139.

— \& 1 1969. Density-dependent gene dispersal in Liatris. Amer. Naturalist 103: 61-74. \& - 1974. Gene flow in seed plants. Evol. Biol. 7: 139-220.

Evolution 25: 113-118.

Mariani, A. \& E. Avieli. 1973. Heterosis during the early phases of growth in intraspecific and interspecific crosses of cotton. Crop Sci. 13: 15-18.

Matzinger, D. F. \& E. A. Wernsman. 1967. Genetic diversity and heterosis in Nicotiana. I. Interspecific cross. Der Züchter 37: 186-191.

May, R. M., J. A. Endler \& R. E. McMurtrie. 1975. Gene frequency clines in the presence of selection opposed by genetic drift. Amer. Naturalist 109: 659-676.

Moll, R. H., J. H. Lonnquist, V. Fortuno \& E. C. Johnson. 1965. The relationship of heterosis and genetic divergence in maize. Genetics 52: 139-144.

Moran, G. F. \& A. H. D. Brown. 1980. Temporal heterogeneity of outcrossing rates in alpine ash (Eucalyptus delegatus R. T. Bak.). Theor. Appl. Genet. 57: 101-105.

Mulcahy, D. L. (editor). 1975. Gamete Competition in Plants and Animals. North Holland Publ. Co., Amsterdam.

NagYlakı, T. 1976. Clines with variable migration. Genetics 83: 867-886.

Nettancourt, D. DE 1977. Incompatibility in Angiosperms. Springer-Verlag, Berlin.

Nilsson, B. D. 1974. Heterosis in an intraspecific hybridization experiment in Norway spruce. Proc. Joint IUFRO Meeting S.02.04: 1-3.

O’Dowd, D. J. \& M. HaY. 1980. Mutualism between harvester ants and a desert ephemeral: Seed escape from rodents. Ecology 61: 531-540.

OrR-Ewing, A. L. 1969. Racial crossing in Douglas fir. Proc. Working Group on Quantitative Genetics Section 22 IUFRO North Carolina State University, Raleigh.

Owino, F. \& B. Zobel. 1977. Genotype $\times$ environment interaction and genotype stability in loblolly pine. III. Heterosis and heterosis $\times$ environment interaction. Silvae Genet. 23: 114-116.

Percival, M. 1965. Floral Biology. Pergamon Press, New York.

Pfahler, P. L. 1965. Fertilization ability of maize pollen grains. I. Pollen sources. Genetics 52: 513-520.

Phillips, M. A. \& A. H. D. Brown. 1977. Mating system and hybridity in Eucalyptus pauciflora. Austral. J. Biol. Sci. 30: 337-344.

Price, M. V. \& N. M. WASER. 1979. Pollen dispersal and optimal outcrossing in Delphinium nelsoni. Nature 277: 294-297.

Proctor, M. \& P. Yeo. 1973. The Pollination of Flowers. Taplinger Publ. Co., New York.

PYKE, G. H. 1978. Optimal foraging: Movement patterns of bumblebees between inflorescences. Theor. Populat. Biol. 13: 72-98.

- , H. R. Pulliam \& E. L. Charnov. 1977. Optimal foraging: A selective review of theory and tests. Quart. Rev. Biol. 52: 137-154.

RoberTS, E. H. 1972. Viability of Seeds. Chapman and Hall, London.

SchaAl, B. A. 1980. Measurement of gene flow in Lupinus texensis. Nature 284: 450-451.

\& D. A. LEVIN. 1976. The demographic genetics of Liatris cylindracea L. Amer. Naturalist 110: 191-206.


Amer. J. Bot. 65: 923-928.

Sheldon, J. C. \& F. M. Burrows. 1973. The dispersal effectiveness of the achene-pappus units of selected Compositae in steady winds with convection. New Phytol. 72: 665-675.

Slatkin, M. 1973. Gene flow and selection in a cline. Genetics 75: 733-756.

1976. The rate of spread of an advantageous allele in a subdivided population. Pp. 767-780

in S. Karlin and E. Nevo (editors), Population Genetics and Ecology. Academic Press, New York.

- \& T. Maruyama. 1975. Genetic drift in a cline. Genetics 81: 209-222.

Sorensen, F. 1969. Embryonic genetic load in coastal Douglas-fir, Pseudotsuga menziesii var. menziesii. Amer. Naturalist 103: 389-398. 
Stapanian, M. A. \& C. C. Smith. 1978. A model for seed scatterhoarding: Coevolution of fox squirrels and black walnuts. Ecology 59: 884-896.

Stern, K. \& L. Roche. 1974. Genetics of Forest Ecosystems. Springer-Verlag, Berlin.

Thomson, J. D. \& R. C. Plowright. 1980. Pollen carryover, nectar rewards, and pollinator behavior with special reference to Diervilla lonicera. Oecologia 46: 68-74.

VICKERY, R. K. 1978. Case studies in the evolution of species complexes in Mimulus. Evol. Biol. 11: $405-407$.

Waddington, K. D. 1979. Flight patterns of three species of sweat bees (Halictidae) foraging at Convolvulus arvensis. J. Kansas Entomol. Soc. 52: 751-758.

1980. Flight patterns of foraging bees relative to density of artificial flowers and distribution of nectar. Oecologia 44: 199-204.

Wang, C. W., T. O. Perry \& A. G. Johnson. 1960. Pollen dispersion of slash pine (Pinus elliottii Engelm.) with special reference to seed orchard management. Silvae Genet. 9: 78-86.

Williams, R. D. \& G. Evans. 1935. The efficiency of spatial isolation in maintaining the purity of red clover. Welsh J. Agric. 11: 164-171.

Wilson, D. E. \& D. H. Janzen. 1972. Predation on Scheelea palm seeds by brucid beetles: Seed density and distance from the parent palm. Ecology 53: 954-959.

Woessner, R. A. 1972. Crossing among loblolly pines indigenous to different areas as a means of genetic improvement. Silvae Genet. 21: 35-39.

Woodell, S. R. J. 1978. Directionality in bumblebees in relation to environmental factors. Pp. 3139, in A. J. Richards (editor), The Pollination of Flowers by Insects. Academic Press, New York.

Wright, J. W. 1953. Pollen dispersion studies: Some practical applications. J. Forest. 51: 114-118.

WRIGHT, S. 1940. Breeding structure of populations in relation to speciation. Amer. Naturalist 74: $232-248$.

1943. Isolation by distance. Genetics 28: 114-138.

1946. Isolation by distance under diverse mating systems. Genetics 31: 39-59.

1951. The genetic structure of populations. Ann. Eugen. 15: 323-354.

1969. Evolution and Genetics of Populations. Vol. 2. Univ. of Chicago Press, Chicago.

Zimmerman, M. 1979. Optimal foraging: a case for random movement. Oecologia 43: 261-267. 


\section{$2 \mathrm{BHL}$ Biodiversity Heritage Library}

Levin, Donald A. 1981. "Dispersal Versus Gene Flow in Plants." Annals of the Missouri Botanical Garden 68, 233-253. https://doi.org/10.2307/2398797.

View This Item Online: $\underline{\text { https://www.biodiversitylibrary.org/item/87380 }}$

DOI: https://doi.org/10.2307/2398797

Permalink: https://www.biodiversitylibrary.org/partpdf/38383

\section{Holding Institution}

Missouri Botanical Garden, Peter H. Raven Library

\section{Sponsored by}

Missouri Botanical Garden

\section{Copyright \& Reuse}

Copyright Status: In copyright. Digitized with the permission of the rights holder.

License: http://creativecommons.org/licenses/by-nc-sa/3.0/

Rights: https://biodiversitylibrary.org/permissions

This document was created from content at the Biodiversity Heritage Library, the world's largest open access digital library for biodiversity literature and archives. Visit BHL at https://www.biodiversitylibrary.org. 